\title{
Validation of Piper methysticum var. wichmannii (Piperaceae)
}

\author{
Wendy L. Applequist \\ Missouri Botanical Garden, P.O. Box 299, St. Louis, Missouri 63166-0299, U.S.A. \\ wendy.applequist@mobot.org
}

Vincent Lebot

CIRAD, P.O. Box 946, Port Vila, Vanuatu.

lebot@vanuatu.com.vu

Abstract. Morphological, chemical, cytological, and genetic data have indicated that kava (Piper methysticum G. Forster, Piperaceae), a vegetatively propagated plant found only in cultivation, was derived from the wild P. wichmannii C. DC. through artificial selection, and that the two taxa remain similar enough to be considered conspecific. A previous attempt to recognize $P$. wichmannii (which may also be conspecific with $P$. subbullatum K. Schumann \& Lauterbach) as a variety of $P$. methysticum was not validly published owing to failure to cite the place of publication of the basionym. The combination Piper methysticum var. wichmannii (C. DC.) Lebot is herein validated.

Key words: kava, New Guinea, Piper, Piper methysticum.

Piper methysticum G. Forster (Piperaceae), commonly known as kava, is cultivated for its kavalactone-containing roots, which are the source of a traditional beverage of the Pacific Islands, and more recently, of phytomedicinals used to alleviate anxiety. Piper methysticum is vegetatively propagated and sterile. Several lines of evidence indicate that it is derived from the wild $P$. wichmannii C. DC., which is occasionally cultivated as an inferior form of kava. Piper wichmannii is fertile and has longer inflorescences and woodier roots, but is otherwise morphologically very similar to $P$. methysticum (Lebot \& Lévesque, 1989). Both taxa are decaploid $(2 n=130$; Lebot et al., 1991). Piper wichmannii is the only known wild taxon that contains significant quantities of kavalactones, as does P. methysticum, and some wild forms of $P$. wichmannii have a chemotype identical to that of certain P. methysticum cultivars (Lebot \& Lévesque, 1996a). An isozyme study (Lebol et al., 1991) found no fixed differences between the two taxa; genetic diversity was limited, especially in $P$. methysticum. Representatives of P. wichmannii and $P$. methysticum from Vanuatu shared identical zymotypes (Lebot et al., 1991), supporting the hypothesis that cultivation of $P$. methysticum may have originated on Vanuatu.

According to Chew (1992), Piper wichmannii is among several taxa that should be placed in synonymy under P. subbullatum Lauterbach \& K. Schumann based on morphological similarities. Gardner (2003) additionally placed the New Guinean P. plagiophyllum K. Schumann \& Lauterbach (which has truncate rather than cordate leaf bases) in synonymy with $P$. subbullatum. Chew's treatment significantly expands the range of the wild progenitor of kava: while $P$. wichmannii has been reported only from New Guinea, the Bismarck Archipelago, the Solomon Islands, and Vanuatu, $P$. subbullatum sensu Chew, including $P$. lageniovarium C. DC., extends into Irian Jaya and the Philippines. However, no chemical or cytological studies of this assemblage are available, except for those that used material of $P$. wichmannii. The opinion that P. subbullatum sensu Chew represents a single species would, for example, be strengthened if kavalactones were discovered in a broader variety of populations.

In any case, Piper methysticum appears to be merely a form of $P$. wichmannii (which may or may not be conspecific with $P$. subbullatum) that has been modified through domestication and artificial selection. Thus, these taxa should be treated as a single species under P. methysticum (Forster, 1786), which name has priority over both $P$. wichmannii (Candolle, 1910 ) and P. subbullatum (Schumann \& Lauterbach, 1900). Because differences in reproductive biology and phytochemical content are significant and of economic importance, a formal distinction between the wild and domesticated populations should be preserved. Lebot in Lebot and Lévesque (1996b: 782) therefore proposed the new combination "Piper methysticum var. wichmannii" to refer to the wild progenitor of kava. That combination was not validly published, because it did not include a "full and direct" reference to the place of valid publication of the basionym as required by Art. 33.3 of the ICBN

Novon 16: 3-4. Published on 25 May 2006. 
(Greuter el al., 2000). The same combination is validated below.

Piper methysticum G. Forster var. wichmamnii (C. DC.) Lebot, comb. et stat. nov. Basionym: Piper wichmannii C. DC., Nova Guinea 8(Bot.) (2): 418. 1910. TYPE: New Guinea. West New Guinea: Côte du Nord, Atasrip 39 [Exped. Wichmann| (holotype, L; isolype, BO, not seen).

Further synonymy, according to Chew (1972, 1992) and Gardner (2003), includes Piper subbullatum K. Schumann \& Lauterbach, P. plagiophyllum K. Schumann \& Lauterbach, P. torricellense Lauterbach in K. Schumann \& Lauterbach, P. grandispicum C. DC., P. lageniovarium C. DC., P. erectum C. DC., P. schlechteri C. DC., P. anisopleurum C. DC., P. pergrande C. DC., and P. arbuscula Trelease. The present authors have not re-examined the types, but suggest that chemical and cytological data to support a broad circumscription would be desirable, most particularly where P. lageniovarium and P. plagiophyllum are concerned, as the former is geographically separated and the latter morphologically distinctive. As a side note, P. methysticum G. Forster has been identified as a later homonym of $P$. methysticum L. f., which, though intended to refer to kava, seems to have been mistakenly based upon material of $P$. latifolium L. f. However, Linnaeus fils (1781) corrected the name to $P$. latifolium in a page of emendations simultaneously published at the end of the volume, conceivably because he had discovered the error. Fosberg (1966) and Smith (1975) have plausibly argued that P. methysticum L. I. was not "accepted by the author in the original publication" as required by Art. 34.1 of the ICBN (Greuter et al., 2000 ) and thus was not validly published, so that no action to conserve $P$. methysticum in its universal meaning is required.

Acknowledgments. This publication was made possible by grant number DHHS 5 P0I ESI05:35 from the National Institute of Environmental Health
Sciences (NIEHS) and the National Center for Complementary and Altemative Medicine (NCCAM), NIH. Its contents are solely the responsibility of the authors and do not necessarily represent the official views of the NIEHS/NCCAM, NIH. The authors thank Nicholas Turland, Victoria Hollowell, and an anonymous reviewer for helpful comments.

Literature Cited

Candolle, A. C. P. de. 1910. Piperaceae. Nova Guinea 8(Bot.) (2): $415-122$.

Chew, W.-I.. 1972. The genus Piper (Piperaceae) in New Guinea. Solomon Islands, and Australia, I. J. Arnold Arbor. 53: 1-2.5.

- 1992. Studies in Malesian Piperaceae II. Blumea $37: 159-164$.

Forster, C. 1786. Forulae insularum australium: Prodromus. Joann, Christian Dietrich, Göttingen.

Fosberg, F. R. 1966. Systematic notes on Micronesian plants. 2. Phytologia 13: 233-241.

Gardner, R. O. 2003. Piper (Piperaceae) in New Guinea: The non-climbing species. Blumea 48: 47-68.

Greuter. W.. J. Mc.Veill, F. R. Barrie, H. M. Burdet, V. Demoulin, T. S. Filgueiras, D. H. Nicolson, P. C. Silva, J. E. Skog, P. Trehane, N. J. Turland \& D. L. Hawksworth (editors). 2000. International Code of Botanical Nomenclature (Saint Louis Code). Regnum Veg. 138.

Lebot, V.\& J. Lévesque. 1989. The origin and distribution of kava (Piper melhysticum Forest. f., Piperaceae): A phylochemical approach. Allertonia 5: 223-280.

— 8 . 1996a. Genetic control of kavalactone chemotypes in Piper methysticum cultivars. PhytochemisIry $43: 397-403$.

— 8 . 1996h. Evidence for conspecificity of Piper methysticum Forst. f. and Piper wichmannii C. IDC. Biochem. Syst. Eicol. 24: 775-782.

—, M. Aradliya \& R. M. Manshardı. 1991. Ceographical survey of genetic variation in kava. Pacific Sci. 4.5(2): $169-185$.

limaeus, C. 1781. Supplementum plantarum Systematis vegetabilium editionis decimae tertiae. Generum plantarum editionis sextae, et Specierum plantarum editionis secunda. Impensis Orphanotrophei, Braunschweig.

Schumann, K. \& K. Lauterbach. 1900. Die Flora der Deutschen Schutzgebiete in der Siulsee. Celoruder Borntraeger, leipzig.

Smith. A. C. 1975. The genus Macropiper (Piperaceae). Bot. J. Linn. Soc. 71: 1-38. 


\section{$2 \mathrm{BHL}$ Biodiversity Heritage Library}

Applequist, Wendy and Lebot, Vincent. 2006. "Validation of Piper Methysticum var. wichmannii (Piperaceae)." Novon a journal of botanical nomenclature from the Missouri Botanical Garden 16, 3-4.

View This Item Online: https://www.biodiversitylibrary.org/item/41804

Permalink: https://www.biodiversitylibrary.org/partpdf/121786

\section{Holding Institution}

Missouri Botanical Garden, Peter H. Raven Library

\section{Sponsored by}

Missouri Botanical Garden

\section{Copyright \& Reuse}

Copyright Status: In copyright. Digitized with the permission of the rights holder.

License: http://creativecommons.org/licenses/by-nc-sa/3.0/

Rights: https://biodiversitylibrary.org/permissions

This document was created from content at the Biodiversity Heritage Library, the world's largest open access digital library for biodiversity literature and archives. Visit BHL at https://www.biodiversitylibrary.org. 